\title{
Sağlık Bilimleri Fakültesi Öğrencilerinin \\ Çocuk İstismarı ve İhmali İle İlgili Görüş ve Düşünceleri ${ }^{*}$
}

\author{
Views and Opinions of Faculty of Health Sciences Students \\ about Child Abuse and Neglect
}

\begin{abstract}
Melahat AKGÜN KOSTAK ${ }^{\mathrm{a}}$ Cemine VATANSEVER ${ }^{\mathrm{b}}$
ÖZET Amaç: Bu çalışma Sağlık Bilimleri Fakültesi öğrencilerinin çocuk istismarı ve ihmali ile ilgili düşüncelerini ve görüşlerini belirlemek amacıyla planlandı. Yöntemler: Tanımlayıcı tipteki araştırmanın örneklemini 397 öğrenci oluşturdu. Veriler anket formu ile toplandı. Verilerin analizinde sayı, yüzde, ortalama ve standart sapma ve ki-kare testi kullanıldı. Bulgular: Öğrencilerin \%11.6'sı çocukluklarında şiddet gördüğünü, \%14.4'ü ihmal edildiğini ifade etti. Öğrencilerin \%40.8'inin çocuk istismar ve ihmali konusunda bilgi aldığı, öğrencilerin bölüm, sınıf ve cinsiyetlerinin bilgi alma durumlarını etkilediği bulundu. Hemşirelik bölümü öğrencilerinin, 4. sınıf öğrencilerinin ve kız öğrencilerin çocuk istismarı ve ihmali ile ilgili daha fazla bilgi aldıkları belirlendi $(\mathrm{p}<0.05)$. "Kızını dövmeyen dizini döver" ifadesine fizyoterapi ve rehabilitasyon bölümü öğrencilerinin ve erkek öğrencilerin daha fazla katıldıkları bulundu ( $p<0.05)$. Sonuç: Çocuk istismarı ve ihmalinin önlenmesi ve erken tanınmasında önemli rolü olan hemşirelik, fizyoterapi ve rehabilitasyon bölümü öğrencilerinin çocuk istismarı ve ihmali konusunda bilgilerinin yetersiz olduğu belirlendi. Öğrencilerin istismar konusundaki farkındalıklarının arttırılması için eğitim programlarının düzenlenmesi, müfredat programlarında istismar konusuna daha fazla yer verilmesi çok önemlidir.
\end{abstract}

Anahtar kelimeler: Çocuk istismar ve ihmali, fizyoterapi ve rehabilitasyon, öğrenci, hemşirelik.

\begin{abstract}
Aim: The aim of the present study was to determine a bout views and opinions of faculty of health sciences students' about child abuse and neglect. Methods: This descriptive study population consisted of students $(\mathrm{n}=397)$. Data were collected using the "Questionnaire Form" and analyzed using number, percentage, mean, standard deviation and chi-square test. Results: In the study, $11.6 \%$ of the students stated that exposed to violence, $14.4 \%$ of the students stated that neglected in their childhood. It is found that only $40.8 \%$ of the students received information about child abuse and neglect, of the students departments, class and gender affected the receive information status. It is found that of nursing students, 4th grade students and female students received more information about child abuse and neglect $(\mathrm{p}<0.05)$. Departments of Physiotherapy and Rehabilitation students and male students approved more likely than nursing students and female students expression of the "Spare the rod spoil the child". $(\mathrm{p}<0.05)$. Conclusion: Of the nursing and physiotherapy and rehabilitation students which play an important role prevention and early assessment to child abuse and neglect information are insufficient about child abuse and neglect. It is important that of the students to increase their awareness of abuse to arrange training programs, to give more space to the subject in the curriculum.
\end{abstract}

Key words: Child abuse and neglect, nursing, physiotherapy and rehabilitation, student.

\footnotetext{
${ }^{a}$ Yard. Doç. Dr. Trakya Üniversitesi Sağlık Bilimleri Fakültesi, Hemşirelik Bölümü, akgunmel@yahoo.com

${ }^{\mathrm{b}}$ Hemşire, Şevket Yılmaz Eğitim Araştırma Hastanesi

Geliş Tarihi 24.08.2014/Kabul Tarihi 05.01.2015

*Çalışma, 26-28 Nisan 2012 tarihleri arasında Bursa'da düzenlenen 11. Ulusal Hemşirelik Öğrencileri Kongresi'nde poster bildiri olarak sunulmuştur.

Yazışma Adresi: Yard. Doç. Dr. Melahat Akgün Kostak, Trakya Üniversitesi Sağlık Bilimleri Fakültesi, Hemşirelik Bölümü, akgunmel@yahoo.com
} 


\section{Giriș}

Tarih boyunca olduğu gibi günümüzde de çocuk istismarı her toplumda rastlanılan ve evrensel boyutu olan bir sorundur. ${ }^{1-3}$ Tüm 1rk ve kültürlerde yaygın olarak görülen istismar, bireylerin doğduğu andan itibaren bulunduğu her ortamda ve çeşitli nedenlerle karşılaşabileceği önemli bir sorundur. ${ }^{1-3}$ Dünya Sağlık Örgütü (DSÖ); çocuk sağlığını, fiziksel ya da psikososyal gelişimini olumsuz etkileyen; bir yetişkin, toplum ya da devlet tarafindan bilerek ya da bilmeyerek yapılan tüm davranışları çocuk istismarı olarak kabul etmektedir. ${ }^{4}$

Türkiye'de çocuk istismarı, çok sık rastlanan ve bazen meşru görülen bir şiddet biçimidir. ${ }^{1,2,4}$ Ülkemizde dayağın bir disiplin yöntemi olarak algılanabildiği ve kullanıldığı dilimize yerleşmiş "Ananın vurduğu yerde gül biter", "Dayak cennetten çıkmadır", "Eti senin kemiği benim" gibi atasözlerinde de kendini göstermektedir. Çocuk İstismarı ve Aile İçi Şiddet Araştırması 2010 Özet Raporu'nda; 7-18 yaș çocukların \%43'ünün fiziksel istismara, \%51'inin duygusal istismara, \%25'nin de ihmale maruz kaldı ̆̆ raporda 7-18 yaş arası çocukların \%56'sinın fiziksel istismara, \%49'unun duygusal istismara ve \%10'unun cinsel istismara tanık olduğu belirtilmektedir. ${ }^{4}$

İstismar ve ihmal s1k görülmesine karşın tanılanmasında, ve bazı istismar türlerinin yasal olarak kanitlanmasında güçlükler yaşanmaktadır. ${ }^{3,5} \mathrm{Bu}$ konunun çocukla çalışan profesyoneller tarafından yeterince tanınmamas1, bildirilmemesi, inkar edilmesi ve gizli kalması ise önemini daha da arttırmaktadır. ${ }^{6}$ Çocuk istismarı ciddi yaralanmalara, sakatlıklara ve hatta ölümlere neden olabilen, çocukta yaşamı boyunca kalıcı izler bırakan, tıbbi, hukuki, sosyal yönleri olan önemli bir sağlik sorunudur. Bununla birlikte çocuk ihmali ve istismar1 önlenebilir bir sorundur. ${ }^{7}$ Sağlık profesyonelleri koruyucu, tedavi edici ve rehabilite edici alanlarda çocuk ve aile ile bir aradadırlar. Çocuk istismarı açısından ailenin risk grubunda olup olmadığının belirlenmesinde önemli rolleri vardır. Bir çalışmada ebe ve hemşirelerin çocuk istismar ve ihmali konusunda bilgilerinin yetersiz olduğu ve bilgi gereksinimlerinin olduğu ${ }^{8}, \quad$ sağlik çalışanları ile yapılan başka çalışmalarda da çocuk istismarı ve ihmali ile ilgili farkındalıklarının yeterli düzeyde olmadığ $1,{ }^{9,10}$ ebelik ve hemşirelik öğrencileriyle yapılan bir çalışmada da öğrencilerin şiddet konusunda hiç bilgi almadıkları belirlenmiștir. ${ }^{11}$ Tüm sağlık profesyonellerinin çalışma alanları ne olursa olsun istismar ve ihmalin erken tanı, tedavisi, önlenmesinde, aile ve toplumun bu konuda bilinçlendirilmesinde aktif rol almaları gerekir. ${ }^{7}$ Literatürde sağlık çalışanlarının şiddete ilişkin eğitiminin, inanç ve tutumları geliştirebileceği belirtilmektedir. ${ }^{9,12,13}$ Koç ve arkadaşları ${ }^{12}$ çalışmalarında ülkemizde çocuk istismarı ve ihmaline ilgi ve duyarlılığın artması ile birlikte istismar ve ihmal tanısı alan olgu sayılarında artış olduğunu belirtmekte, aynı çalışmada bunun yeterli düzeyde olmadığ 1 da vurgulanmaktadır. Çocuk istismarı ve ihmalinin önlenmesinde sağlık profesyonellerinin çocuk istismar ve ihmalinde rol oynayan risk faktörlerini bilmeleri önemlidir.

Yaşanan her türlü istismar daha sonra bireyin sosyal yaşamında hatalı bir istismar algısının oluşumunda temel oluşturur. Bireylerin algıladığı istismar düzeyi onun kuracağı ilişkilerin yapısını ve içeriğini etkileyen önemli faktörlerden biridir. ${ }^{14} \mathrm{Bu}$ nedenle, sağlık profesyonellerinin eğitimleri sirasında şiddet konusuna daha fazla yer verilmeli ve öğrencilerin kültürel özelliklerinden getirdikleri şiddete yönelik tutum ve görüşlerinin değiştirilmesine çalışılmalıdır. Bunun için öncelikle öğrencilerin çocuk istismarı ve ihmaline ilişkin görüş ve düşüncelerinin bilinmesi önemlidir. $\mathrm{Bu}$ açıdan bakıldığında geleceğin sağlık profesyonellerinin çocuk istismarı ve ihmali konusundaki bilgi ve görüşlerinin saptanması hazırlanacak eğitim programlarına rehber olacaktır. Hemşirelik ve fizyoterapi ve rehabilitasyon bölümü 
öğrencilerinin çocuk istismarı ve ihmali ile ilgili düşüncelerinin, görüşlerinin ve bunları etkileyen faktörlerin bilinmesi, şiddete ilişkin farkındalığın arttırılması ve şiddetin önlenmesi açısından önemlidir. $\mathrm{Bu}$ çalışma Sağlık Bilimleri Fakültesi hemşirelik ve fizyoterapi ve rehabilitasyon bölümü öğrencilerinin çocuk istismarı ve ihmali ile ilgili düşüncelerini ve görüşlerini belirlemek amaciyla planlandı.

\section{Gereç ve Yöntemler}

Tanımlayıcı tipteki araştırmanın evrenini; 2011-2012 bahar yarıyılında bir Sağlık Bilimleri Fakültesi'nin hemşirelik $(\mathrm{N}=386)$ ve fizyoterapi ve rehabilitasyon $(\mathrm{N}=219)$ bölümlerinin 1., 2., 3. ve 4. sinıflarında öğrenim gören toplam 605 öğrenci oluşturdu. Araştırmaya 27 Mart-04 Nisan 2012 tarihlerinde derslere devam eden, araştırmaya katılmayı kabul eden 253 hemşirelik, 144 fizyoterapi ve rehabilitasyon bölümü $(n=397)$ öğrencisi katıld1.

Veriler, araştırmacılar tarafından literatür bilgisi doğrultusunda ${ }^{7,9,11,13,15}$ geliştirilen "Anket Formu" ile topland1. Anket formu, öğrencilerin sosyodemografik özelliklerini içeren (sınıf, yaş, cinsiyet, bölüm, aile tipi, ekonomik durum, kardeş sayısı vb.) 9 soru, şiddet ile ilgili özelliklerini içeren (şiddete maruz kalma, ihmal edilme, eğitimi sirasında şiddet hakkında bilgi alma vb.) 3 soru, çocuk istismarı ve ihmali ile ilgili görüş ve düşüncelerini içeren "Katıllyorum", "Kararsızım" ve "Katılmıyorum" şeklinde yanitlanan 14 olmak üzere toplam 26 sorudan oluştu. Anket formu, örneklem grubuna uygulanmadan önce her iki bölümden seçilen 20 öğrenciye uygulandı. Ön uygulama sonrası gerekli düzenlemeler yapılarak son şekli verildi. $\mathrm{Bu}$ anket formları örnekleme dahil edilmedi. Formlar sözlü onayı alınan gönüllü öğrencilere uygun ders saatleri içinde uyguland1 ve geri topland1. Anketlerin yanıtlaması 6-8 dakika sürdü.

\section{İstatistiksel Analiz}

Araştırmanın verileri SPSS 16.0 programında analiz edildi. Öğrencilerin sosyodemografik özellikleri, çocuk istismarı ve ihmali ile ilgili görüşleri sayı, yüzde, ortalama ve standart sapma ile değerlendirildi. Öğrencilerin bazı sosyodemografik özellikleri (sınıf, cinsiyet, bölüm vb.) ile çocuk istismarı ve ihmali ile ilgili düşünce ve görüşlerinin karşılaştırılmasında ki-kare testi kullanıldı. $\mathrm{p}<0.05$ değeri istatistiksel anlamlılık sınırı olarak kabul edildi.

\section{Etik Yaklaşım}

Araştırma için Sağlık Bilimleri Fakültesi Dekanlığ 1 ve Hemşirelik Bölüm Başkanlığı'ndan yazılı izin alındı. Anket formları dağıtılmadan önce öğrencilere araştırmanın amacı açıklandı. Araştırmaya katılmaya gönüllü öğrencilere anket formlarına isim yazmamaları, elde edilen bilgilerin bilimsel amaçla kullanılacağı söylendi ve sözel onamları alındı.

\section{Bulgular}

Araştırmaya katılan öğrencilerin yaş ortalamas1 $20.4 \pm 1.7, \quad \% 74.6$ 's1 k1z, \%63.7'si hemşirelik, \%36.3'ü fizyoterapi ve rehabilitasyon bölümünde okumakta idi. Öğrencilerin \%84.6'sının aile tipi çekirdek, $\% 44.8$ 'i iki kardeş, \%51.4'ünün annesi, \%36.8'inin babas1 ilkokul mezunuydu. Araştırmaya katılan öğrencilerin \%84.9'u gelir düzeylerini orta olarak tanımladı (Tablo 1). Öğrencilerin şiddete ilişkin bazı özellikleri incelendiğinde; \%11.6'sının çocukluklarında şiddet gördüğü, \%14.4'ü ihmal edildiği, \%40.8'inin eğitimleri sırasında çocuk istismar ve ihmali konusunda bilgi aldığ 
Sağllk Bilimleri Fakültesi Öğrencilerinin Çocuk İstismarı ve İhmali İle İlgili Görüşv ve Düşünceleri

Tablo 1: Öğrencilerin bazı sosyo-demografik Özellikleri $(n=397)$

\begin{tabular}{|c|c|}
\hline Özellikler & $\mathbf{n}(\%)$ veya Ort \pm SD (Ortalama ve standart sapma) \\
\hline Yaş, yıl & $20.4 \pm 1.7$ (min:17-max:31) \\
\hline \multicolumn{2}{|l|}{ Cinsiyet } \\
\hline $\mathrm{K} 1 \mathrm{Z}$ & $296(74.6)$ \\
\hline Erkek & $101(25.4)$ \\
\hline \multicolumn{2}{|l|}{ Bölüm } \\
\hline Hemşirelik & $253(63.7)$ \\
\hline FTR & $144(36.3)$ \\
\hline \multicolumn{2}{|l|}{ Sinıf } \\
\hline 1.sinif & $162(40.8)$ \\
\hline 2. sinif & $114(28.7)$ \\
\hline 3. sinif & $89(22.4)$ \\
\hline 4. $\sin 1 f$ & $32(8.1)$ \\
\hline \multicolumn{2}{|l|}{ Aile tipi } \\
\hline Çekirdek & $336(84.6)$ \\
\hline Geniş & $52(13.1)$ \\
\hline Parçalanmış & $9(2.3)$ \\
\hline \multicolumn{2}{|l|}{ Kardeş sayısı } \\
\hline 1 & $33(8.3)$ \\
\hline 2 & $178(44.8)$ \\
\hline 3 & $96(24.2)$ \\
\hline 4 & $40(10.1)$ \\
\hline 5 ve üzeri & $50(12.7)$ \\
\hline \multicolumn{2}{|l|}{ Anne eğitimi } \\
\hline Okuryazar değil & $30(7.6)$ \\
\hline İlkokul & $204(51.4)$ \\
\hline Ortaokul & $60(15.1)$ \\
\hline Lise & $74(18.6)$ \\
\hline Üniversite & $29(7.3)$ \\
\hline \multicolumn{2}{|l|}{ Baba eğitimi } \\
\hline Okuryazar değil & $7(1.8)$ \\
\hline İlkokul & $146(36.8)$ \\
\hline Ortaokul & $63(15.9)$ \\
\hline Lise & $113(38.5)$ \\
\hline Üniversite & $68(17.1)$ \\
\hline \multicolumn{2}{|c|}{ Ekonomik durum } \\
\hline İyi & $38(9.6)$ \\
\hline Orta & $337(84.9)$ \\
\hline Kötü & $22(5.5)$ \\
\hline
\end{tabular}

Tablo 2. Öğrencilerin Şiddete İlişkin Özellikleri (n=397)

\begin{tabular}{lc}
\hline Özellik & $\mathbf{n}(\%)$ \\
\hline Çocukluğunda şiddet maruz kalma & \\
Evet & $46(11.6)$ \\
Hayır & $351(88.4)$ \\
Çocukluğunda ihmal edilme & \\
Evet & $57(14.4)$ \\
Hayır & $340(85.6)$ \\
Eğitimleri surasında çocuk istismar ve & \\
ihmali konusunda bilgi alma & \\
Evet & $162(40.8)$ \\
Hayır & $235(59.2)$ \\
\hline
\end{tabular}


Tablo 3. Öğrencilerin çocuk istismarı ve ihmaliyle ilgili düşünce ve görüşleri

\begin{tabular}{|c|c|c|c|}
\hline İFADELER & 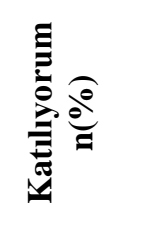 & 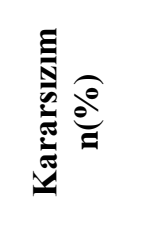 & 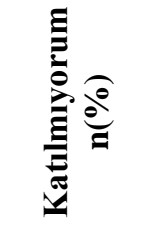 \\
\hline Fiziksel istismar çocuğun sağlığını tüm boyutlarıyla etkiler. & $334(84.1)$ & $46(11.6)$ & $17(4.3)$ \\
\hline $\begin{array}{l}\text { Eğitim düzeyi düşük anne-babalar çocuklarını daha fazla } \\
\text { istismar ve ihmal ederler. }\end{array}$ & $216(54.4)$ & $78(19.6)$ & $103(25.9)$ \\
\hline $\begin{array}{l}\text { Ailedeki çocuk sayısı çocuk istismar ve ihmalinin } \\
\text { oluşmasında etken değildir. }\end{array}$ & $63(15.9)$ & $112(28.2)$ & $222(55.9)$ \\
\hline Anne yaşının çocuk istismar ve ihmalinde önemi yoktur. & $53(13.4)$ & $58(14.6)$ & $286(72.0)$ \\
\hline $\begin{array}{l}\text { Çocuk istismar ve ihmaline üst sosyoekonomik düzeylerde } \\
\text { rastlanmaz. }\end{array}$ & $27(6.8)$ & $96(24.2)$ & $274(69.0)$ \\
\hline $\begin{array}{l}\text { Kendisi istismar ya da ihmale uğrayan anne-babalar } \\
\text { çocuklarına da bunu uygular. }\end{array}$ & $102(25.7)$ & $183(46.1)$ & $112(28.2)$ \\
\hline $\begin{array}{l}\text { Planlanmamış gebelik sonucunda doğan çocukların istismar } \\
\text { edilme olasılıkları daha fazladır. }\end{array}$ & $202(50.9)$ & $101(25.4)$ & $94(23.7)$ \\
\hline $\begin{array}{l}\text { Doğumlar arası sürenin kısa olması çocuğun istismar ve } \\
\text { ihmale uğramasını etkiler. }\end{array}$ & $229(57.7)$ & $99(24.9)$ & $69(17.4)$ \\
\hline $\begin{array}{l}\text { Ebeveynin alkol ya da ilaç bağımlısı olması çocuk istismar } \\
\text { ve ihmali açısından bir risktir. }\end{array}$ & $361(90.9)$ & $26(6.5)$ & $10(2.5)$ \\
\hline $\begin{array}{l}\text { Ailenin geniş ya da çekirdek aile tipinde olması çocuk } \\
\text { istismar ve ihmalinde önemli bir faktördür. }\end{array}$ & $195(49.1)$ & $119(30.0)$ & $83(20.9)$ \\
\hline $\begin{array}{l}\text { Ebeveynin fiziksel ve mental sağlık sorunlarının olması } \\
\text { çocuğunu istismar ve ihmal etmesini etkilemez. }\end{array}$ & $57(14.4)$ & $68(17.2)$ & $272(68.5)$ \\
\hline $\begin{array}{l}\text { Özel bakım gerektiren çocuklar daha çok istismara maruz } \\
\text { kalır. }\end{array}$ & $178(44.8)$ & $148(37.3)$ & $71(17.9)$ \\
\hline $\begin{array}{l}\text { Ebeveynlerden birinin olmaması çocuk istismarı ve ihmali } \\
\text { için bir risktir. }\end{array}$ & $256(64.5)$ & $86(21.7)$ & $55(13.9)$ \\
\hline "Kı1zını dövmeyen dizini döver." & $60(15.1)$ & $63(15.9)$ & $274(69.0)$ \\
\hline
\end{tabular}

Öğrencilerin çocuk istismarı ve ihmali ile ilgili bazı düşünce ve görüşleri incelediğinde; \%84.1'inin "Fiziksel istismar çocuğun sağlığını tüm boyutlarıyla etkiler.”, \%54.4'ünün "Eğitim düzeyi düşük anne-babalar çocuklarını daha fazla istismar ve ihmal ederler.", \%15.9'unun "Ailedeki çocuk sayısı çocuk istismar ve ihmalinin oluşmasında etken değildir.", \%13.4'ünün "Anne yaşının çocuk istismar ve ihmalinde önemi yoktur" ifadesine "katılıyorum" yanıtını verdikleri, \%69'unun "Çocuk istismar ve ihmaline üst sosyoekonomik düzeylerde rastlanmaz" ifadesine katılmadikları bulundu. Öğrencilerin \%25.7'si 'Kendisi istismar ya da ihmale uğrayan anne-babalar çocuklarına da bunu uygular." ifadesine katıldıkları belirlendi. Öğrencilerin \%50.9'unun 'Planlanmamış gebelik sonucunda doğan çocukların istismar edilme olasılıkları daha fazladır.", \%57.7'sinin "Doğumlar arası sürenin kısa olması çocuğun istismar ve ihmale uğramasını etkiler." \%90.9'unun "Ebeveynin alkol ya da ilaç bağımlısı olması çocuk istismar ve ihmali açısından bir risktir." ifadesine katıldıkları bulundu (Tablo 3).

Öğrencilerin \%49.1'inin “Ailenin geniş ya da çekirdek aile tipinde olması çocuk istismar ve ihmalinde önemli bir faktördür.", \%44.8'inin "Özel bakım gerektiren çocuklar daha çok istismara maruz kalır.", \%64.5'inin "Ebeveynlerden birinin olmaması çocuk istismarı ve ihmali için bir risktir." ifadelerine katıldıkları belirlendi. Öğrencilerin \%15.1'inin "Kızını dövmeyen dizini döver" ifadesine katıldığ1, \%15.9'unun ise "Kararsızım" yanıtını verdiği bulundu (Tablo 3). Öğrencilerin bölüm, sınıf ve cinsiyetlerine 
göre eğitimleri sırasında çocuk istismarı ve ihmali ile ilgili bilgi alma durumları arasında istatistiksel anlaml fark bulundu $(\mathrm{p}<0.05)$ (Tablo 4).

Tablo 4. Öğrencilerin Bölüm, Sınıf, Cinsiyet ve Şiddet Görme Durumlarına Göre Eğitimleri Sırasında Çocuk İstismarı ve İhmali ile İlgili Bilgi Alma Durumları

\begin{tabular}{|c|c|c|c|c|c|}
\hline \multirow{2}{*}{$\begin{array}{l}\text { Özellikler } \\
\text { Bölüm }\end{array}$} & \multicolumn{2}{|c|}{ Bilgi Alan } & \multicolumn{2}{|c|}{$\begin{array}{c}\text { Bilgi } \\
\text { Almayan }\end{array}$} & \multirow{4}{*}{$\begin{array}{c}\chi^{2} \mathbf{p} \\
X^{2}=29.938 \\
\mathbf{p}<\mathbf{0 . 0 0 1}\end{array}$} \\
\hline & $\mathbf{n}$ & $\%$ & $\mathbf{n}$ & $\%$ & \\
\hline Hemşirelik & 129 & 51.0 & 124 & 49.0 & \\
\hline FTR & 33 & 22.9 & 111 & 77.1 & \\
\hline \multicolumn{6}{|l|}{ Sinıf } \\
\hline 1.sinif & 53 & 32.7 & 109 & 67.3 & \multirow{4}{*}{$\begin{array}{c}X^{2}=20.201 \\
\mathbf{p}<\mathbf{0 . 0 0 1}\end{array}$} \\
\hline 2.sinif & 41 & 36.0 & 73 & 64.0 & \\
\hline 3.sinif & 46 & 51.7 & 43 & 48.3 & \\
\hline 4.sinif & 22 & 68.8 & 10 & 31.3 & \\
\hline \multicolumn{6}{|l|}{ Cinsiyet } \\
\hline $\mathrm{K} 1 \mathrm{Z}$ & 132 & 44.6 & 164 & 55.4 & $X^{2}=6.914$ \\
\hline Erkek & 30 & 20.7 & 71 & 70.3 & $p=0.009$ \\
\hline \multicolumn{6}{|c|}{ Şiddet görme } \\
\hline Evet & 27 & 16.7 & 135 & 83.3 & $X^{2}=6.894$ \\
\hline Hayır & 19 & 8.1 & 216 & 91.9 & $p=0.009$ \\
\hline
\end{tabular}

Hemşirelik bölümü öğrencilerinin, 4. sınıf öğrencilerinin ve kız öğrencilerin eğitimleri sırasında çocuk istismarı ve ihmali ile ilgili daha fazla bilgi aldıkları belirlendi. Öğrencilerin şiddet görme durumları ile eğitimleri sırasında çocuk istismarı ve ihmali ile ilgili bilgi alma durumları arasında da istatistiksel anlamlı ilişki vard $1(p=0.009)$. Şiddet görmediğini belirten öğrencilerin eğitimleri sırasında çocuk istismarı ve ihmali ile ilgili bilgi almadikları belirlendi (Tablo 4). Öğrencilerin bölüm ve cinsiyetleri ile "Kızını dövmeyen dizini döver" sözüne katılma durumları arasında istatistiksel anlamlı fark bulundu. "Kızını dövmeyen dizini döver" ifadesine hemşirelik bölümü öğrencilerinin ve k1z öğrencilerin daha fazla katılmadıkları bulundu (Tablo 5). 
Tablo 5. Öğrencilerin bölüm ve cinsiyetlerine göre "kızını dövmeyen dizini döver" ifadesi hakkındaki görüş̧leri

\begin{tabular}{|c|c|c|c|c|c|c|c|}
\hline \multirow{3}{*}{ Özellik } & \multicolumn{6}{|c|}{ “Kızını dövmeyen dizini döver” } & \multirow{3}{*}{$\begin{array}{l}\text { Anlamlılık } \\
\text { Düzeyi }\end{array}$} \\
\hline & \multicolumn{2}{|c|}{ Katıliyorum } & \multicolumn{2}{|c|}{ Kararsızım } & \multicolumn{2}{|c|}{ Katılmıyorum } & \\
\hline & $\mathbf{n}$ & $\%$ & $\mathbf{n}$ & $\%$ & $\mathbf{n}$ & $\%$ & \\
\hline \multicolumn{8}{|l|}{ Bölüm } \\
\hline Hemşirelik & 29 & 31.0 & 40 & 15.8 & 184 & 72.7 & $X^{2}=7.544$ \\
\hline FTR & 40 & 21.5 & 23 & 16 & 90 & 62.5 & $\mathbf{p}=\mathbf{0 . 0 2 3}$ \\
\hline \multicolumn{8}{|l|}{ Cinsiyet } \\
\hline K1z & 23 & 7.8 & 46 & 15.5 & 227 & 76.7 & $X^{2}=51.511$ \\
\hline Erkek & 37 & 36.6 & 17 & 16.8 & 47 & 46.5 & $\mathbf{p}<0.001$ \\
\hline
\end{tabular}

\section{Tartışma}

Çalışmaya 397 Sağlık Bilimleri Fakültesi öğrencisi katıldı. Araştırmada, çalışmaya katılan Sağlık Bilimleri Fakültesinde öğrenim gören hemşirelik ve fizik tedavi ve rehabilitasyon bölümü öğrencilerinin \%11.6'sının çocukluk döneminde şiddete maruz kaldığı, \%14.4'ünün ihmal edildiği belirlendi. Bozkurt ve ark. $^{13}$ bir yüksekokulda ebelik öğrencileriyle yaptıkları çalışmalarında öğrencilerin \%40.6'sının aile içi şiddete maruz kaldığını, \%36.2'sinin aile içinde şiddete tanık olduğunu, Tunçel ve ark. ${ }^{11}$ ebelik ve hemşirelik öğrencileriyle yaptıkları çalışmada öğrencilerin \%60.1'inin çocukluk döneminde anne ve babaları tarafindan fiziksel şiddete maruz kaldıklarını , \%44.7'sinin anne ve babaları arasındaki fiziksel şiddete tanık olduklarını belirlemiştir. Çetinkaya ve ark. ${ }^{16}$ üniversite öğrencileriyle yaptıkları çalışmalarında, \%42.3'ünün duygusal, \%35.3'ünün sözel, \%26.3'ünün fiziksel ve \%9.3'ünün ekonomik şiddete maruz kaldıklarını ya da şahit oldukları tespit edilmiştir. Annelerle yapılan bir başka çalışmada ise annelerin \%87.4'ünün çocuklarına en az bir kez fiziksel istismar/ihmal davranışı uyguladıkları, \%93'ünün çocuklarını duygusal olarak istismar/ihmal ettikleri belirlenmiştir. ${ }^{17}$ Çalışma sonuçlarına bakıldığında bulgular arasında farklılıklar olmasına karşın şiddetin öğrencilerin yaşamında varlığı dikkat çekmektedir. Bu çalışmada öğrencilerin şiddet ve ihmale maruz kalma durumlarının benzer çalışma sonuçlara göre daha düşük bulunması, çalışmaların yapıldığı yılların ve bölgelerin farklılığına, dolayısıyla öğrencilerin kültürel şiddet alg1ları ve istismar ile ilgili bilgi ve deneyimlerinin farklılığına bağlanabilir.

Çalışmada, araştırmaya katılan fakülte öğrencilerinin \%40.8'i eğitimleri sırasında çocuk istismarı ve ihmali hakkında bilgi aldıklarını ifade etmiştir. Tunçel ve ark. ${ }^{11}$ sağlık yüksekokulunda ebelik ve hemşirelik öğrencilerinin \%10.6'sının aile içi şiddet konusunda bilgi aldıklarını, Kostak ve $\operatorname{Kocaaslan}^{18}$ da Sağlık Bilimleri Fakültesi öğrencilerinin duygusal şiddet algılarının zayıf olduğunu buldu. Kocaer'in ${ }^{19}$ çalışmasında hekimlerin \%46.6's1, hemşirelerin \%27.9'u öğrenimleri sırasında çocuk istismarı ve ihmali konusunda eğitim aldıklarını, ancak çoğu bu eğitimin yeterli olmadığını belirtmişlerdir. Gölge ve arkadaşları ${ }^{9}$ da hekim ve hemşirelerle yaptığı çalışmada yarıdan fazlasının eğitimleri sırasında çocuk istismarı ve ihmali konusunda bilgi aldıklarını, mezuniyet sonrası ise çok azının konuyla ilgili eğitimlere katıldıklarını saptadı. Yağmur ve Balc1 ${ }^{20}$ birinci basamak sağlık çalışanlarının \%16.6'sının çocuk istismarı konusunda eğitim aldığını, ülkemizde bu konuda verilen eğitimin yetersiz olduğunu, sağlık çalışanlarına bu konuda eğitim verilmesinin gerekliliğini belirtirken, sağlık çalışanlarının bu konudaki yasal 
sorumlulukların da bilmediklerini de ifade etmişlerdir. Uncu ve Oğuzöncül $1^{10}$ çalışmasında sağlık bakım çalışanlarının çocuk istismarı ve ihmali konusunda farkındalıklarının artırılması için bu konuda eğitim yapılmasının gerekliliğini vurgulamaktadır.

Duman ve ark. ${ }^{21}$ çalış̧malarında şiddet konusunda eğitim ile sağlık ekibinin duyarlılı̆̆ının arttırılabileceği, sağlık ekibinin şiddete ilişkin eğitiminin inanç ve tutumları geliştirebileceği belirtilmiştir. Son yillarda ülkemizde de çocuk istismarının müfredatta yer aldığı ve mezuniyet sonrası konu ile ilgili hizmet içi eğitimlerde bir artış olduğu görülmektedir. ${ }^{9}$ Gölge ve ark. ${ }^{9}$ çalışmalarında öğrenimleri sırasında çocuk istismarı hakkında bilgi aldıklarını belirten sağlık çalışanlarının belirtmeyenlere göre "istismar ve ihmale yatkın ebeveynlerin özellikleri" alt ölçeğinden aldıkları puanlarının daha yüksek olduğunu belirlemiş̧lerdir.

Çalışmaya göre öğrencilerin çocuk istismarı ve ihmali ile ilgili bilgileri yeterli düzeyde değildir. Öğrencilerin $\% 84.1$ ' $\mathrm{i}$ "Fiziksel istismar çocuğun sağlığını tüm boyutlarıyla etkiler", \%54.4'ü "Eğitim düzeyi düşük anne-babalar çocuklarını daha fazla istismar ve ihmal ederler", \%15.9'u "Ailedeki çocuk sayısı çocuk istismar ve ihmalinin oluşmasında etken değildir", \%13.4'ü "Anne yaşının çocuk istismar ve ihmalinde önemi yoktur" ifadesine "Katıliyorum" yanıtını vermişlerdir. Çocuk istismar ve ihmalinin önlenmesinde en önemli yol, istismar ve ihmalin oluşmasına neden olacak risk faktörlerinin önceden belirlenmesi, risk faktörlerinin ortadan kaldırılması ve istismarın önlenmesidir. Çatık ve Çam ${ }^{8}$ hemşire ve ebelerle yaptıkları çalışmalarında \%52.6'sının çocuk istismarı ve ihmalinin belirti ve risklerini tanıma konusunda eğitim almadıklarını, \%89.1'inin ise bu konuda bilgi gereksinimlerinin olduğunu belirlemişlerdir. Ülkemizde bu konuda araştırmaların sınırlı olması, mezuniyet öncesi ve sonrası eğitimlere yer verilmeye yeni başlanması, sağlık çalışanlarında bilgi ve deneyim eksikliği nedeniyle olgular gözden kaçmaktadır. ${ }^{22} \mathrm{Bu}$ nedenle öğrencilerin istismar konusundaki farkındalıklarının arttırılması için eğitim programlarının düzenlenmesi, lisans eğitimi müfredat programlarında istismar konusuna daha fazla yer verilmesi çok önemlidir.

Türkiye'de toplumun, çocuk sağlığı ile ilgilenen profesyonellerin çocuk istismarı konusundaki farkındalıkları düşüktür. ${ }^{6}$ Toplumun sosyal ve kültürel özellikleri, çocuk büyütme ve yetiştirilmesine yönelik gelenek ve görenekleri çocuk istismarına yaklaşımı ve tanısını etkileyen temel bir faktördür. Çocukların fiziksel ve duygusal olarak istismar edilmeleri çocuğun aile içinde disipline edilmeleri için gerekli görülmektedir. Pek çok kişi bunu normal olarak karşılamakta ve çocuğun istismar edildiği düşünülmemektedir. Yolcuoğlu'nun ${ }^{23}$ aktarımında Zeytinoğlu(1991)'na göre ebeveynin çocuklarına yönelik hangi eylemlerin çocuk istismarı ve ihmali olduğu; o toplumda çocuğa verilen değere, toplumun değerleri ve inançlarına, ceza ve disiplin yöntemlerine, çocuğa yönelik kabul edilebilir ve kabul edilemez davranışlarının neler olduğuna bağlı olarak şekillenmektedir. Türk ailesinin çocuk yetiştirme biçimi genellikle ataerkil otoriteye dayanan, kısıtlayıcı ve aşırı koruyucu ana-baba tutumlarını içermekte ve çocuktan beklenti olarak da saygilı olma, boyun eğme, uysallık ve kurallara uygun davranma talep edilmektedir. Bu çalışmada öğrencilerin \%15.1'inin “Kızını dövmeyen dizini döver" ifadesine katılmas1, \%15.9'unun ise "Kararsizım" yanıtını vermesi bu görüşü yansıtmaktadır. Aynı şekilde çalışan hemşire ve ebelerle yapılan bir çalışmada, ${ }^{15} \% 12.7$ 'sinin fiziksel şiddete uğradıklarını belirtmesi ve aynı çalışmada "Anne babanızdan dayak yediniz mi?" sorusuna \%44.9'unun evet yanıtını vermesi de aynı görüşü desteklemektedir. Başka bir çalışmada da 
aile içinde şiddet öyküsü olan sağlık çalışanlarının "Erkekler doğası gereği saldırgandır.", "Evde, okulda, disiplini sağlamak için şiddet kullanılabilir." ifadelerine daha fazla katılmaları da bu bulguları desteklemektedir. ${ }^{24} \mathrm{Bu}$ çalışma ve diğer çalışma bulguları bize sağlık çalışanlarının ve geleceğin sağlık çalışanlarının şiddet algılarının kültürel özelliklerden olumsuz etkilendiğini göstermektedir. $\mathrm{Bu}$ nedenle, sağlik profesyonellerinin eğitimleri sirasında şiddet konusuna daha fazla yer verilmesi ve öğrencilerin kültürel özelliklerinden getirdikleri şiddete yönelik olumsuz tutum ve görüşlerinin değiştirilmesi önemlidir.

$\mathrm{Bu}$ çalışmada "Kızını dövmeyen dizini döver" ifadesine hemşirelik bölümü öğrencilerinin (\%72.7) ve kız öğrencilerin (\%76.7) daha fazla katılmadıkları belirlendi. Özgür ve ark. ${ }^{25}$ öğrencilerin cinsiyetlerinin şiddet eğilimlerini etkilediğini, erkek öğrencilerin şiddet ve saldırganlık eğilimlerinin fazla olduğunu buldu. Kız öğrencilerin "Kızını dövmeyen dizini döver" ifadesine katılmamaları bu ifadenin kız çocuklarına yönelik şiddeti onaylaması ve kızların istismara daha fazla maruz kalmaları ile açıklanabilir. Ayrıca hemşirelik bölümü öğrencilerinin bu ifadeye daha fazla katılmaması da hemşirelik bölümü öğrencilerinin çoğunun kızlardan oluşmasının bir sonucu olarak da değerlendirilmiştir.

Çalışmada hemşirelik bölümü öğrencilerinin (51.0), 4. sinıf öğrencilerinin (68.8) ve kız öğrencilerin (44.6) eğitimleri sırasında çocuk istismarı ve ihmali ile ilgili daha fazla bilgi aldıkları belirlendi. Kostak ve Kocaaslan $^{18}$ da aynı şekilde Sağlık Bilimleri Fakültesi öğrencileri ile yaptıkları çalışmalarında, kız öğrenciler ile fiziksel ve duygusal istismara maruz kalan öğrencilerin duygusal istismar kapsamına giren davranışları daha fazla tanıdıklarını belirlemiştir. Hemşirelik bölümü öğrencilerinin fizyoterapi bölümü öğrencilerine göre çocuk istismarı ve ihmali ile ilgili daha fazla bilgi almaları, hemşirelik bölümü müfredatında bu konulara daha fazla yer verilmesi ve hemşirelik bölümü öğrencilerinin daha çok kızlardan oluşması ile açıklanabilir. Çalışmada 4. sınıf öğrencilerinin çocuk istismar1 ve ihmali ile ilgili daha fazla bilgi almaları eğitimlerinin ilerlemesine paralel beklenen ve olumlu bir sonuç olarak değerlendirilmiştir.

Daha önce şiddete maruz kalmadığını belirten öğrencilerin, eğitimleri sırasında çocuk istismarı ve ihmali ile ilgili bilgi almadıkları belirlendi. Bireylerin şiddete ilişkin bilgi ve algıları daha önceki yaşantılarını değerlendirmelerini etkiler. ${ }^{14}$ Öğrencilerin kültürel özellikleri ve kişisel deneyimlerinin şiddete ilişkin tutumlarını etkilemesi, şiddet hakkındaki bilgi ve algılarının yeterli düzeyde olmaması, gerçek anlamda şiddeti tanımlamalarını engellemektedir. Dolayısıyla şiddet ile ilgili bilgi almayan öğrencilerin şiddet görmediğini belirtmeleri beklenen bir sonuçtur.

\section{Sonuç}

Çocuk istismar ve ihmalinin önlenmesi ve erken tanınmasında önemli rolü olan geleceğin sağlik profesyonelleri hemşirelik, fizyoterapi ve rehabilitasyon bölümü öğrencilerinin \%40.8'inin eğitimleri sırasında çocuk istismarı ve ihmali konusunda bilgi aldığı, öğrencilerin bölüm, sınıf ve cinsiyetlerinin bilgi alma durumlarını etkilediği bulundu. Öğrencilerin istismar konusundaki farkındalıklarının arttırılması için eğitim programlarının düzenlenmesi, müfredat programlarında istismar konusuna daha fazla yer verilmesinin çok önemli olduğu sonucuna varıldı. Düzenlenecek eğitim programlarında öğrencilerin bölüm, sınıf, cinsiyetlerinin ve kültürel özelliklerinin dikkate alınması önerilebilir.

\section{Kaynaklar}

1.Polat O. Çocuk istismarı ve Türkiye'deki durumu. Klinik Çocuk Forumu 2004;1: 1-11.

2. Çağlarırmak A. Yerleşik olan ve olmayan ailelerde çocuk istismarı 
yaygınlığının incelenmesi. Yayınlanmamış Yüksek Lisans Tezi, Ege Üniversitesi, Sosyal Bilimler Enstitüsü, İzmir, 2006.

3. Kırımsoy, E. Şuç İşlemiş ve Suç İşlememiş Ergenlerin Algıladıkları Duygusal İstismarın ve Benlik Saygılarının Karşılaştırmalı Olarak İncelenmesi. Ankara Üniversitesi Eğitim Bilimleri Enstitüsü Yayınlanmamış Yüksek Lisans Tezi, Ankara, 2003.

4. Türkiye'de Çocuk İstismarı ve Aile İçi Şiddet Araştırması Özet Raporu 2010.

5. Aksel Ş. Duygusal istismar ve ihmal. Gelişimsel yaklaşım. Klinik Çocuk Forumu 2004; 1: 1-11.

6. Dereobalı N, Karadağ SÇ, Sönmez S. Okulöncesi eğitim öğretmenlerinin çocuk İstismari, ihmali, şiddet ve eğitimcilerin rolü konusundaki görüşleri. Ege Eğitim Dergisi 2013; 14(1): 50-66.

7. Altıparmak S. Çocuk istismar ve ihmalinin çocuk bedeni üzerine etkisi. Çocuk Dergisi 2008; 8(1):9-13.

8. Çatık A, Çam O. Hemşire ve ebelerin çocuk istismarı ve ihmalinin belirti ve risklerini tanıma düzeylerinin saptanması. Ege Üniversitesi Hemşirelik Yüksek Okulu Dergisi 2006; 22(2):103-119.

9. Gölge ZB, Hamzaoglu N, Türk B. Sağlık alışanlarının çocuk istismari ve ihmali konusundaki farkındalık düzeylerinin ölçülmesi. Acil Tıp Dergisi 2012; 26(2):86-96.

10. Uncu F, Oğuzöncül AF. Health care workers who work in the province of elazig levels of awareness about child abuse and neglect, and the factors affecting this situation. Int J Med Invest. 2013; 2(3):129-142.

11. Tunçel EK, Dündar C, Peşken Y. Ebelik ve hemşirelik öğrencilerinin aile içi şiddet konusunda bilgi ve tutumlarının değerlendirilmesi. Genel Tip Derg 2007;17(2): 105-110.

12. Koç F, Akşit S, Tomba A, Aydın C, Koturoğlu G, Cetin SK, Aslan A, Halıcıoğlu O, Erşahin Y, Turhan T, Celik A, Şenol E, Kara S, Solak U. Çocuk istismarı ve ihmali olgularımızın demografik ve klinik özellikleri: Ege
Üniversitesi Çocuk Koruma Birimi'nin bir yıllık deneyimi. Türk Ped Arş 2012; 47: 119-24.

13. Bozkurt ÖD, Daşıkan Z, Kavlak O, Şirin A. Ebelik öğrencilerinin gebelikte şiddet konusundaki bilgi, görüş ve mesleki tutumlarının belirlenmesi. Balıkesir Sağlık Bil Derg 2013; 2(2): 99-107.

14. Ersanlı K, Yilmaz M, Özcan K. Alg1lanan Duygusal İstismar Ölçeği (ADİÖ): Geçerlik ve güvenirlik çalışması. Ondokuz Mayıs Üniversitesi Eğitim Fakültesi Dergisi 2013; 32(1): 147-164.

15. Elmalı F, Erten ZK, Zincir H., Özen B., Balcı E. Hemşire ve ebelerin aile içi fiziksel şiddete bakış açıları maruziyetleri. Sağlık Bilimleri Dergisi 2011; 20(1) 39-47. 16. Çetinkaya SK. Üniversite Öğrencilerinin şiddet eğilimlerinin ve toplumsal cinsiyet rollerine ilişkin tutumlarının incelenmesi. Nesne 2012;1(2):21-43.

17. Güler N, Uzun S, Boztaş Z, Aydoğan $S$. Anneleri tarafından çocuklara uygulanan duygusal ve fiziksel istismar/ihmal davranışı ve bunu etkileyen faktörler. C. Ü. Tıp Fakültesi Dergisi 2002; 24 (3):128134.

18. Kostak MA, Kocaaslan EN. Faculty of Health Science Students' Perseption Levels of Emotional Abuse and Affecting Factors. p.958- 967. In: A Current Perspective on Health Sciences.Ed. Kaptanoğlu AY. Rotipo 2014.

19. Kocaer Ü. Hekim ve Hemşirelerin Çocuk İstismarı ve İhmaline Yönelik Farkındalık Düzeyleri. Marmara Üniversitesi Sağlık Bilimleri Enstitüsü Yüksek Lisans Tezi, İstanbul, 2006.

20. Yağmur F, Balcı E. Kayseri ili merkez ve ilçeleri birinci basamak sağlık çalışanlarının, çocuk istismarı ve ihmali konusunda bilgi düzeyleri: Anket çalışması. Adli Bilimler Dergisi 2009; 2 : 14-23.

21. Duman ZÇ, Özdağ Ş, Özcan A. Aile içi şiddetin çocuk üzerindeki etkisi konusunda hemşire öğrencilerin görüşleri. Atatürk Üniv. Hemşirelik Yüksekokulu Dergisi 2003; 2: 50-56. 
22. Kara Ö, Çalışkan D, Suskan E. Ankara ilinde görev yapan çocuk asistanları, uzmanları ve pratisyen doktorların çocuk istismar1 ve ihmali konusunda bilgi düzeyleri ve yaklaşımlarının karşılaştırılması. Türk Ped Arş 2014; 49: 57-65.

23. Yolcuoğlu İ.G. Çocukların ihmalistismara uğramasında aile ve çocuklara yönelik risk faktörleri ve sosyal hizmet müdahalesi. Toplum ve Sosyal Hizmet 2010; 21(1): 73-83.

24. Şahin NH, Dişsiz M, Sömek A, Dinç H. Sağlık çalışanlarının aile içi şiddet deneyimleri ve bu konudaki yaklaşımlarının belirlenmesi. Hemşirelikte Araştırma Geliştirme Dergisi 2008; 2: 1731.

25. Özgür G, Yörükoğlu G, Baysan LA. Lise öğrencilerinin şiddet algıları, şiddet eğilim düzeyleri ve etkileyen faktörler. Psikiyatri Hemşireliği Dergisi 2011; 2(2):53-60. 